\title{
PEDAGOGIAS CULTURAIS, CORPOS HETEROTÓPICOS E POSSIBILIDADES NÃO-NORMATIVAS: A FORMAÇ̃̃O DOCENTE EM EXPERIÊNCIAS COM UM JOGO DE RPG
}

\section{CULTURAL PEDAGOGIES, HETEROTOPIC BODIES, AND NON-NORMATIVE POSSIBILITIES: TEACHER TRAINING INEXPERIENCES WITH A RPG GAME}

\section{RESUMO}

A pesquisa reflete sobre os regimes discursivos que engendram e se materializam em torno da construção de identidades e subjetividades não-normativas que rompem a coerência corpo-sexo-gênero-sexualidade. Analisa como futuras/os educadoras/es acionam percepções e significados acerca das questões de gênero e sexualidade nos atos performativos vivenciados na experiência com o jogo de RPG (Role Playinggame), no que se referem às transidentidades e suas subjetividades. Para esse fim, utilizou-se a pesquisa-ação-participativa, desenvolvida com 30 estudantes de Pedagogia pertencentes a duas Instituições de Ensino Superior do Paraná. A proposta possibilitou constatar a necessidade de formação dos/as docentes para a sensibilidade aos temas, no sentido de prepará-los/as para atuarem com consciência nos diferentes espaços educativos, sendo sensíveis aos danos sociais, culturais e psíquicos causados pela manutenção de modos de exclusão criadores de zonas de apagamento.

Palavras-chave: Identidades. RPG. Formação Docente.

\begin{abstract}
The research is focused on the discursive regimes that engender and materialize the construction of non-normative identities and subjectivities that break the coherence between body-sexuality and gender. It analyzes how future educators trigger perceptions and meanings about gender and sexuality issues in the performative acting experienced in the RPG (Role Playing-game), with regard to trans identities and their subjectivities. For this purpose, we used the research-action-participation, developed with 30 Pedagogy students of two colleges in the state of Paraná. The proposal allowed us to notice the need to educate teachers to be aware of the themes' sensitivity, in the sense of preparing them to act consciously in the different educational environments, by being sensitive to the social, cultural, and psychic damages caused by the maintenance of exclusionary modes that create exclusionary areas.
\end{abstract}

Keywords: Identities. RPG. Teacher Training.

Cássia Cristina Furlan

Universidade Federal da Grande Dourados (UFGD). E-mail: cassiafurlan@ufgd.edu.br 


\section{Introdução}

As Pedagogias ${ }^{1}$ culturais estão intrinsecamente relacionadas aos processos de construção e fabricação de identidades e subjetividades. Existem múltiplas pedagogias se proliferando por meio de artefatos, dispositivos disciplinares e enunciados discursivos que atuam direta ou indiretamente no modo como as pessoas se narram, se apresentam e se materializam no tempo presente. As pedagogias, sendo construções culturais, atuam em conjunção com a cultura para penetrar, mediar e produzir os modos de ser e viver contemporâneos.

Nesse sentido, propomos o debate acerca dos modos como diferentes verdades circulantes nas práticas sociais contemporâneas - engendradas em noções biologicistas e deterministas de corpo - vão reproduzindo uma dimensão constitutiva de corpos-sujeitos de modo binário e excludente. Aquilo que dizemos e consideramos existir de forma "natural" e não problemática, são construções humanas, declarações e categorizações de determinados grupos sociais tornadas "verdadeiras" em certo momento histórico, as quais integram os processos constitutivos dos sujeitos. É importante salientar que tais pedagogias são produtivas; os artefatos da cultura são pedagógicos ao nos ensinarem modos de ser a partir da regulação das nossas condutas (ANDRADE, 2016; SOUZA, 2016).

Desse modo, refletindo sobre a pulsão da obra O corpo utópico, as heterotopias (FOUCAULT, 2013), debruçamo-nos sobre as realidades dos corpos que sofrem invisibilidades numa sociedade marcadamente heteronormativa e excludente, situados em um campo de disputas e de luta por garantia de direitos. Assim, temos como objetivo desta pesquisa analisar como futuras/os educadoras/es acionam percepções e significados acerca das questões de gênero e sexualidade na interpretação de papéis em uma experiência com o jogo de RPG ${ }^{2}$. Nesse contexto, ao refletir sobre

1 O conceito de Pedagogia não pode ser entendido como uma produção linear de sentidos. Nesse recorte, trabalhamos com as articulações entre Pedagogia e Cultura, entendendo que não existe um conceito unívoco de Pedagogia, mas que toda pedagogia envolve interações com a Cultura, com a produção de saberes, dentro de espectro de relações de poder que a subjazem. Como um conjunto de saberes e práticas, a(s) pedagogia(s) estão centradas nos sujeitos e na sua formação, nos tempos e espaços que o constituem. Portanto, pedagogias compõem as dinâmicas que sustentam a construção das subjetividades.

2 O RPG (Role Playing-Game ou Jogo de interpretação de papéis) constitui um jogo de ficção do tipo que envolve o/a mestre/a e os/as jogadores/as, chamados/as de players. Os/as jogadores/as, à medida que o jogo transcorre, vão interpretando seus/suas personagens na história ao mesmo tempo em que jogam, lembrando um teatro. O/a mestre/a é representado/a por um/a jogador/a escolhido/a pelo grupo (nesta pesquisa foi a pesquisadora). "O jogo se desenvolve em torno da criação de histórias e a participação de personagens dando vida à história. Existe um mestre, cuja função é expor as regras da história, problematizar os/as personagens da história e ambientá-los/as em relação ao contexto inicial de desenvolvimento do jogo. Os/As participantes criam personagens com características próprias que farão parte do jogo. O/a mestre/a inicia a interpretação do jogo e as/os participantes vão representando e modificando o rumo do jogo, de acordo com a situação que criam no decorrer da história. O jogo não tem uma história fixa, pois são os/as próprios/as personagens que darão vida aos/às personagens. O/A mestre/a deve guiar e problematizar a história, de acordo com as fantasias criadas pelos/as personagens. Esta representação é verbal, aproximando-se de uma leitura de texto (como a que antecede os ensaios no palco), mas sem texto. Alguns[mas] jogadores[as] interpretam de modo descritivo, em terceira pessoa 
os significados atribuídos discursiva e culturalmente aos gêneros, desejamos colocar em evidência como se engendram e se materializam os regimes discursivos em torno da coerência corpo(sexo)-gênero-sexualidade, buscando algumas possibilidades para se pensar a produção de resistências a dispositivos de controle que refletem processos de assujeitamento dos corpos à matriz heteronormativa. A ordem estabelecida, as expressões de sexualidades, a produção ficcional dos sexos, os desejos, todas essas questões se inserem numa lógica binária. Por meio das relações de força, tensionamos os padrões de normalidade numa dimensão questionadora de discursos tomados como verdades absolutas, produzindo, a partir das experiências, possibilidades de repensá-las. "Como vamos saber a diferença entre o poder que promovemos e o poder ao qual nos opomos? [...] O problema, por certo, é que não se pode saber isso antecipadamente, de modo que a recitação subversiva sempre envolverá certa dose de risco" (SALIH, 2015: 136). De tal modo, arriscamo-nos a uma recitação subversiva acerca dos deslocamentos identitários dos corpos trans e das sexualidades que fogem ao padrão da heterossexualidade compulsória, com suporte nas performances do jogo.

Para tal fim, este estudo baseou-se na metodologia da pesquisa-açãoparticipativa (COSTA, 2007). Esse método de pesquisa dialoga com a vertente dos Estudos Culturais e dos Estudos de Gênero, na concepção de Fabiane Freire França (2014), na medida em que favorece a afirmação das identidades dos indivíduos, construindo narrativas que podem constituir-se em formas de resistência e contestação às narrativas socialmente legitimadas e hegemônicas, falando de experiências historicamente constituídas desde o lugar que ocupam, sabendo, contudo, dos obstáculos referidos a esse tipo de pesquisa, valorizando o diálogo e a escuta na produção de saberes que possam questionar e desestabilizar a produção de saberes hegemônicos alçados em noções de normalidade.

Partindo dessa perspectiva, a abordagem empírica da pesquisa buscou analisar os atos performativos vivenciados na prática com o RPG entre estudantes (11 acadêmicas) de Pedagogia participantes do PET (Programa de Educação Tutorial) da Universidade Estadual de Maringá/UEM - sede (Cidade de Ártemis³) e 19 acadêmicas do último ano do curso de Pedagogia de uma faculdade particular da cidade de Cornélio Procópio (FaCP) (Cidade de Pandora).

\footnotetext{
(“[minha]meu personagem faz isso, ele[ela] diz aquilo"), outros/as em primeira pessoa ("eu pego minha espada e saio gritando pelo corredor"). [...] Trata-se de um jogo de fantasia, que nasce da fantasia do autor[a] ou de um grupo de autores[as]. Ora, o sucesso de um jogo nasce da capacidade desta criação representar a fantasia dos[as] jogadores[as], assim como uma criação artística" (ANDRADE, 2015, s/p.).

3 Para a dinâmica do jogo e a explanação dentro da pesquisa, as acadêmicas foram inseridas em cidades fictícias, conforme a seu pertencimento universitário (Ártemis - UEM e Pandora - FaCP). Quando citadas na pesquisa, utilizamos o nome criado pelas participantes para sua/seu personagem e a cidade fictícia ao qual pertenciam (Exemplo: Cristiane - Ártemis).
} 
Nas intervenções ${ }^{4}$, ancoramo-nos na utilização do jogo Trilhas da Diversidade: microrrevoluções $(R P G)^{5}$, sendo um jogo de fantasia, de atuação, de construções performativas de personagens e histórias. O objetivo do jogo de RPG não é ganhar, mas completar uma história. Nesse contexto, personagens, histórias pessoais de vida e todas as características dos/as personagens (interpretados pelas acadêmicas da pesquisa), foram criadas pelas próprias participantes, de modo que realmente se inserissem no âmbito ficcional da brincadeira. No enredo de jogo, as realidades a que os/as personagens foram submetidos/as nas histórias perpassavam temas como: subjetividades homoafetivas. transidentidades, relações de gênero desiguais, violências de gênero, violências homofóbicas, preconceitos, dentre outras ${ }^{6}$.

Uma partida inicia-se quando o/a mestre lança desafios, situações-problema, ou com um objetivo, uma busca. Os desafios propostos pelo/a mestre constituem a provocação para a construção coletiva da história. Escolhemos o RPG para as intervenções porque o mesmo possibilita um criar e recriar de estórias que não se limitam a produções discursivas a priori, ou seja, não se limitam a discursos fabricados que necessariamente se reproduzem sem reflexão. O RPG proporciona aos/às personagens agir performaticamente, de acordo com suas vontades e desejos, sem se reprimirem ou sentirem-se pressionados/as para tais ações, representando um/a personagem criado/a para o jogo. Além disso, possibilita reconstruir situações e vivências a todo o momento. Durante uma partida de RPG, criam-se universos imaginários e há o compartilhamento de vivências no próprio processo do jogo (CABALEIRO, 2007). As situações foram vividas pelos/as personagens em cada contexto experienciado na história criada pelo jogo, inicialmente apenas sendo coadjuvantes e observando o que acontecia ao seu redor, decidindo ou não tomar alguma atitude e, posteriormente sendo chamadas a agirem e a participarem diretamente das cenas montadas no jogo.

Para a dinâmica do jogo, havíamos separado algumas situações que seriam desenvolvidas em ambas as cidades (Ártemis e Pandora). No entanto, o jogo ganha vida própria e é conduzido pelas respostas das jogadoras, não sendo possível controlar todos os caminhos. Logo, a direção em que se sucederam as estórias não é linear, nem as mesmas.

Frequentemente o grupo de personagens se divide, ou a ação se foca em apenas alguns/mas personagens, deixando outros/as de fora - como foi o caso das nossas

4 Foram realizados 5 encontros para as intervenções com o RPG (3 encontros de aproximadamente 2 horas com Ártemis e 2 encontros com Pandora).

5 A explicação do jogo Trilhas da Diversidade: microrrevoluções e o modo como é desenvolvido o RPG estão contidas na tese da qual esse recorte faz parte: FURLAN, Cássia Cristina. Performances em jogo: (des)construindo experiências em gênero, sexualidade e identidades na prática com o RPG. 277f. Tese (Doutorado em Educação) - Universidade Estadual de Maringá. Orientadora: Dra. Eliane Rose Maio. Maringá, 2017.

6 Dados os diferentes temas e abordagens, em muitos momentos e situações do jogo, as performances se misturavam com diálogos da realidade e, portanto, as reflexões surgiram tanto das significações atribuídas às vivências do jogo quanto por meio do jogo. Devido à dimensão dessa comunicação, nos limitaremos a apresentar as performances e reflexões do jogo no tocante aos corpos trans e suas subjetividades. 
intervenções. Nesse emaranhado de situações reais e imaginárias, os/as personagens também enfrentam seus próprios dilemas sobre o que é real, conforme avançam por meio de diferentes planos de sua própria realidade e tomam decisões acerca de conflitos expressos na trama.

Nesse sentido, as contribuições de Michel Foucault (FOUCAULT, 1988; 1996; 1997; 2000; 2013), alinhavadas às percepções feministas e dos Estudos Culturais, forneceram aportes teóricos para a leitura do material produzido a partir das experiências com o RPG, visando pensar a educação e as possibilidades de construção identitária de outros modos, questionando os limites binários instaurados nos discursos construtores das performances.

\section{Identidades de gênero e subjetividades trans: deslocamentos, abjeções e práticas}

Pensar na constituição das subjetividades e dos corpos é refletir sobre as distintas condições de leitura e análise dos poderes e da instituição das verdades nos discursos sobre esses corpos nas sociedades. A subjetividade constitui forma simultaneamente desfeita por processos de subjetivação ${ }^{7}$, mas captada pelos saberes e poderes; é um processo que participa da potência de diferenciação do corpo, com relação aos modos de subjetivação e às práticas de si (ANDRADE, 2012). Não existe uma forma mais verdadeira de ser homem ou mulher, mas configurações de políticas que se efetivam mediante interpretações negociadas com as idealizações do feminino e do masculino, que ao serem invocadas, garantem aos sujeitos agir performaticamente interpretando as normas de gênero (BUTLER, 2003; BENTO, 2006; NAVARRO-SWAIN, 2002; LOURO, 2007a e b). O trabalho de fabricação das identidades é permanente, de caráter inconcluso; mas em muitos setores da sociedade acaba por legitimar certos modos de ser e estar no mundo, de acordo com as figurações corporais consideradas coerentes com o sexo biológico. É nesse contexto que nos empenhamos em refletir sobre as identidades que não se encaixam na "normalidade" embasada no pressuposto da heteronormatividade, abrindo espaço para pensar as possibilidades de mudanças e fissuras nessas normas, denunciando as tentativas de fixar e homogeneizar as identidades.

A essência natural e imposta ao corpo em discursos naturalizadores passa a ser questionada visto que só podemos apreender a materialidade do corpo através do discurso que é ele mesmo produtor das relações generificadas, sexualizadas,

7 Tudo nos subjetiva (FISCHER, 2007); os processos e influências interferem no modo como construímos nossas identidades. Alguns processos de subjetivação agem como estatutos de verdade, para consolidar identidades e práticas sociais. Práticas de subjetivação também são formas de objetivação, isto é, dos modos como o sujeito foi objeto de saber e de poder, para si mesmo e para os/as outros/as. Nesse sentido, o corpo é um lugar político, onde se operam as práticas de sujeição e os modos de subjetivação ora como mecanismos de controle, ora em suas formas de resistência. 
racializadas, que se produzem a partir de jogos de poder-saber (POCAHY; DORNELLES, 2010; PRECIADO, 2011).

As noções produtoras de um "verdadeiro sexo" da qual decorrem as imagens que identificam os gêneros constituem-se performativamente a partir dos discursos que antecedem os sujeitos. Como pondera Butler (2003), essa materialidade se dá em sua relação com a matriz heteronormativa que, ao reiterar discursivamente imagens corporais que se enquadram na matriz de gênero, constituem o domínio do desumanizado e do abjeto $^{8}$, ou seja, aqueles que não se encaixam na inteligibilidade de gênero.

A atitude epistemológica e política de opor-se radicalmente às noções de essência, como apontado por Preciado (2011) possibilita visualizar os/as sujeitos/as não inteligíveis, como mulheres lésbicas, homens gays, mulheres e homens travestis e transexuais e as pessoas que não se localizam facilmente nessas categorias do binarismo de gênero, ousando evidenciar na materialidade de seus corpos o afrontamento à relação de continuidade e consequência corpo(sexo) $\rightarrow$ gênero $\rightarrow$ sexualidade (prazer e desejo).

Logo, do mesmo modo que a linguagem reitera normas de gênero e é a causa da opressão sexual, também pode ser o caminho para ir além dessa lógica, possibilitando a proliferação e subversão das estruturas de poder, pois a interpelação nem sempre coloca efetivamente em ação o que nomeia, posto que os sujeitos estão implicados nas mesmas estruturas de poder, sendo habilitados por ela e não simplesmente subordinados à lei (BUTLER, 2003; SALIH, 2015).

Vale pontuar que, como na pesquisa de Bento (2006), não nos enredamos na discussão de gênero a partir da referência biológica, mas das performances que os/ as sujeitos/as constroem em suas vidas cotidianas para serem reconhecidos/as como membros/as legítimos do gênero com o qual se identificam. A partir dessa vertente é que pensamos a possibilidade de desnaturalização e reinvenção das identidades de gênero, nessa pesquisa.

Para Bento (2006), as reflexões dentro dos movimentos feministas têm reservado um espaço pequeno para as travestis, os/as transexuais, as lésbicas, os gays, os/as transgêneros/as e tantas outras experiências identitárias. Tais sujeitos/as, segundo a perspectiva adotada pela autora, constituem suas identidades mediante os mesmos processos que os considerados "normais".

Com relação à experiência trans, o dispositivo da transexualidade, organizado na lógica consubstanciada por Foucault (1988), tem-se construído por um conjunto de acontecimentos, produções discursivas, teses científicas, pesquisas, experiências e

8 A teórica Julia Kristeva (1982, p.4) chama tais grupos expulsos ou excluídos de "abjetos", cujo significado em latim é, literalmente, "expulsos". Escreve que "não é a falta de limpeza ou saúde que causa a abjeção, mas, sim, aquilo que perturba a identidade, o sistema, a ordem. Aquilo que não respeita limites, posições, regras. O entremeio, ambíguo, o misturado". Para Butler (2003), no âmbito das possibilidades performativas de gênero encontra-se a construção de um conjunto de corporeidades e vivências que não são reconhecidas como inteligíveis no tecido social, pois não se produzem dentro do que determina a norma. Sujeitos/as assim enquadrados/as estão nas "zonas de abjeção", chamam-se abjetos/as, tornados "Outros/as". 
instituições sociais que procuram garantir a legitimidade das identidades de gênero, classificando e ordenando as subjetividades. Para compreender em quais condições o dispositivo da transexualidade (LIMA, 2014; BENTO, 2006) foi forjado é preciso entendê-lo no contexto de medicalização do corpo individual e social, que teve início nas transformações entre os séculos XVIII e XIX, quando a sexualidade passou gradativamente, como salienta Foucault (1988), pelo domínio das relações entre saber e poder. Para Lima (2014), talvez a transexualidade ${ }^{9}$ tenha surgido da necessidade de patologizar e classificar tais sujeitos, diferenciando-os/as da homossexualidade e da intersexualidade.

Nesse contexto, o termo transgênero se refere a uma pessoa que não se reconhece no gênero decorrente de sua genitália, ou seja, sente que pertence ao gênero oposto ou pertence a ambos ou a nenhum dos dois sexos tradicionais, incluindo-se nessas categorias travestis, transexuais, intersexuais, Drag Queens e Drag Kings.

O dispositivo da transexualidade opera como um marcador de gênero, interpelando modos de vida que não se organizam na lógica e decorrência binária. Muitas pessoas transgêneros produzem-se e orientam-se pelos discursos biomédicos, e tais discursos têm o poder de fazer as pessoas trans assumirem o modelo biomédico, o qual as patologiza, tanto no plano físico como no plano mental, induzindo-as a submeterem-se aos aparatos médicos reguladores, uma vez que, em alguns países, conforme Ávila e Grossi (2010), ainda é necessário passar pela cirurgia para a obtenção do reconhecimento legal e social da identidade de gênero trans.

Como salienta Bento (2006), a norma de gênero repete que somos o que nossa genitália permite ver. Muitos/as acabam se considerando anormais, refugiando suas dores na sua subjetividade, não conseguindo perceber os dispositivos sociais que atuam na produção das normas.

Nesse substrato histórico e político, a transexualidade se situa como um dos fenômenos da biopolítica contemporânea. Entretanto, no âmbito do próprio dispositivo operam tanto processos de assujeitamento que reforçam códigos culturais, discursos e práticas heteronormativas quanto possibilidades de vazar e/ou subverter a lógica do dispositivo (LIMA, 2014).

9 Em meados de 1950, após a primeira cirurgia de emasculação, surge o conceito de 'transexualismo', formulado pelo médico norte-americano Harry Benjamin. Surgiu para nomear um distúrbio relativo à identidade sexual em pacientes submetidos a tratamentos hormonais e cirúrgicos para a transformação da aparência sexual, por acreditarem pertencer ao sexo oposto (CAETANO; GARCIA, 2010). Em 1987, a transexualidade, chamada de transexualismo, foi incluída no Diagnostic and Statistical Manual of Mental Disorders - DSM III (Manual Diagnóstico e estatístico das Desordens Mentais) para os indivíduos com "disforia de gênero" que demonstrassem durante, pelo menos, dois anos, um interesse contínuo em transformar o sexo do seu corpo e o status do seu gênero social. Em 1994, o DSM-IV trocou o termo Transexualismo por Desordem da Identidade de Gênero, que também pode ser encontrado no CID-1o (Classificação Internacional de Doenças) (Athayde, 2001) e, na sua última versão, em 2001, o DSM trocou "Desordem" por "Transtorno de Identidade de Gênero" (AVILA; GROSSI, 2010, p.5). Cabe destacar que, desde 2018, a transexualidade deixou de ser classificada como doença. Naquele ano, a Organização Mundial da Saúde (OMS), lançou uma nova edição da Classificação Estatística Internacional de Doenças e Problemas Relacionados com a Saúde (CID) e, nela, a transexualidade, até então entendida como "transtorno de identidade de gênero", deixa de ser uma "doença mental", contudo, continua incluída no catálogo como "incongruência de gênero". (OMS, 2018). 
Assim, considerar as experiências trans pela ideia de patologia reduz as singularidades e possibilidades de modos de existência desses sujeitos. O gênero é uma repetição estilizada de atos (BUTLER, 2003), mas como tal, nas diferentes maneiras de repetição, há possibilidades de ruptura ou repetição subversiva desses atos. Butler (2003) abriu espaço para a inclusão de experiências de gênero transcendentes ao referente biológico interpretado como citações de uma suposta origem.

Desse modo, as performances de gênero das travestis, das transexuais e das drags queens e kings impõem a construção de novas reflexões, uma vez que existem pluralidades em trânsito com a emergência de movimentos e identidades que não se legitimam nas explicações biológicas centradas no corpo como referência natural e óbvia acerca dos gêneros.

O corpo não é referente absoluto para posicionar os/as sujeitos/as em mundos polarizados de gênero, como mostra o dilema que envolve o corpo do/a transexual, pois já não se sustenta uma percepção corporal e anatômica supostamente estável a partir, por exemplo, da vestimenta que adorna o corpo. São perguntas que emergem desse contexto: “Será homem? Será mulher?". Conforme Bento (2006: 108), as categorias masculino/feminino como construídas pelas normas de gênero não mais dão conta de responder a tais perguntas. Talvez fosse melhor perguntar: "Afinal, o que é um homem? E uma mulher?"

Nessa perspectiva, adentramos as situações do jogo, evidenciando algumas questões pertinentes a outras possibilidades identitárias. Uma das personagens de Ártemis, que se construiu no jogo como personagem trans (Cristiane), foi ambientada a participar de uma cena dentro de um mercado e é inserida na situação de questionamento: "Será que é homem ou é mulher?" (MESTRE $\left.{ }^{10}\right)$.

Cristiane - Ártemis: Eu sou mulher. Tenho que pensar numa resposta educada, espera aí. Traveco não, eu sou mulher trans e eu acho que educação parte de você. De interferir na minha vida, sendo que eu vim aqui só comprar algumas coisas. E é isso, não interfira na minha vida que eu não te dou respostas grossas.

$[\ldots]$

Mestre: Ele [caixa do mercado] fala assim: Esse povo começa a ver problema em tudo hoje, não pode falar mais nada, sempre está violentando alguém.

Cristiane - Ártemis: Mas eu não disse que estava me violentando, eu disse que estava invadindo minha privacidade, se eu quisesse

\footnotetext{
10 Como já explicitado, a/o mestre do jogo expõe as regras do jogo, proporciona a ambientação dos/ as personagens nas histórias ficcionais e vai produzindo, juntamente com o grupo, a continuidade da história e diversas problematizações e provocações (em sua grande maioria, visando expor preconceitos e/ou desestabilizar as personagens em cena) representando personagens inseridos/as por ela/e na história (chamados de Non Player Character - NPC, ou seja, personagens controlados pela mestra) para que os/as participantes se posicionem enquanto personagens participantes das diferentes cenas. As falas produzidas pela mestra do jogo estão sublinhadas ao longo do texto.
} 
que as pessoas soubessem que eu era trans eu andava com uma coisa na testa escrito que eu era trans.

Mestre: Aí ele fala: Mas dá pra ver na sua cara.

Cristiane - Ártemis: Que bom, então. Que bom que você conseguiu descobrir. Eu espero que você me respeite e só.

Em seguida, Dinho, outro personagem trans de Ártemis, também passa por uma situação semelhante. Ao avistar Dinho na rua, um policial comenta, em tom de desconfiança: "Nossa, ele é transexual, achei que fosse homem de verdade" (MESTRE).

Dinho - Ártemis: Que diferença que isso faz pra você? Eu sou homem.

Mestre: Aí ele diz: Mas isso é o que você está falando que é, não que você nasceu sendo.

Dinho - Ártemis: Eu nem entraria numa discussão. Eu ignoraria na verdade. Só perguntaria: que diferença isso faz pra você [...].

Cristiane e Dinho, sentindo-se incomodados/as por terem sua identidade de gênero julgada e questionada, posicionam-se pela garantia de respeito. Ao passarem pela situação como personagens principais, vivenciam momentos de afronta e violência às suas identidades.

As identidades que se representam a partir dos modos de vida e construção do corpo travesti e transexual acabam sendo produzidas como o avesso da norma. E variados são os olhares reguladores, patologizantes, que classificam e nomeiam as experiências que fogem à norma. Apesar dos avanços nos movimentos e na conquista por direitos das populações LGBTTTQIA ${ }^{11}$, ainda persistem as referências negativas que invisibilizam as identidades, negando a garantia de espaços de cidadania ativa a essas populações. Apesar de as travestis e as transexuais terem conquistado a "[...] possibilidade de sobreviver no centro, e não apenas à margem da sociedade, elas ainda sofrem com os estereótipos do passado, pois ainda são vistas como sinônimo de marginal e atentado ao pudor, uma espécie de afronta à moral e aos bons costumes" (ANDRADE, 2012: 16). Criam-se, nestes contextos, estereótipos que acabam por determinar modos de ser, estar e se representar. Mas o que são estereótipos de gênero? Para Stuart Hall (2016: 191-192)

[...] a estereotipagem reduz, essencializa, naturaliza e fixa a "diferença". Em segundo lugar, a estereotipagem implanta uma estratégia de "cisão", que divide o normal e aceitável do anormal e inaceitável. Em seguida, exclui ou expele tudo o que não cabe, o que é diferente. [...] Simbolicamente, ela fixa os limites e exclui tudo o que nãolhe pertence. A estereotipagem, em outras palavras, é parte da manutenção da ordem social e simbólica. Ela estabelece

11 Lésbicas, Gays, Bissexuais, Travestis, Transexuais, Transgêneros, Queer, Intersexo e Assexuais. 
uma fronteira simbólica entre o "normal" e o "pervertido", o "normal" e o "patológico", o "aceitável" e o "inaceitável", o "pertencente" e o que não pertence ou é o "Outro", entre "pessoas de dentro" (insiders) e "forasteiros" (outsiders), entre nós e eles. $[\ldots]$ o terceiro ponto é que a estereotipagem tende a ocorrer onde existem enormes desigualdades de poder.

Tais estereótipos são observados nas representações das personagens de Pandora, ao encenarem uma situação em que estão presentes sujeitos/as trans sofrendo preconceitos. Na situação vivenciada, como não há nenhuma personagem trans, elas participam como expectadoras. O episódio acontece na entrada de uma balada, quando uma travesti é ofendida por alguns homens que estão na fila de entrada do estabelecimento. Eles a ofendem dizendo: "Olha que traveco!" (MESTRE), em sentido pejorativo. Na sequência, uma mulher que também passava por lá diz: "Não é porque se veste como mulher que pode ser uma" (MESTRE).

Lia - Pandora: É homem?

Isabelle - Pandora: É essa aqui ó, uma travesti, e a outra (mostrando a imagem ${ }^{12}$ ).

Lia - Pandora: Não é porque se veste como mulher que pode ser uma?

Laurinha Star - Pandora: É, e ela é mulher?

Lia - Pandora: Ela é homem (em tom afirmativo e sarcástico). (gargalhadas)

Giovanna - Pandora: você parece um traveco, fala assim então.

Isabelle - Pandora: Não, mas foi a outra que falou, a mulher, a mulherzinha.

Lia - Pandora: Ela não parece traveco não, ó. O outro é que é traveco.

Isabelle - Pandora: Então, né, essa aqui.

Lia - Pandora: E ela não falou isso pra outra?

Giovana - Pandora: Falou: Não é só porque você se veste como uma mulher que você pode ser uma mulher.

Lia - Pandora: igual você aí, ó. Igual você. Também tá parecendo um travecão aí nessa foto (gargalhada).

Ao se situarem na cena, Lia, Isabelle e Giovana agem em tom de deboche, demonstrando como os estereótipos estão presentes na interpretação que fazemos das pessoas. Ao visualizarem uma pessoa que aparentemente foge aos padrões ditos femininos, explicitam certos preconceitos repetidos na cena, chamando-a de traveco, usando esse termo também em referência à outra mulher da cena.

A interpretação das personagens retoma a questão: será homem ou mulher? Reproduz-se na cena o padrão segundo o qual é preciso situar as pessoas nesses

12 Todas as cenas iniciais foram ambientadas a partir de tirinhas construídas para o jogo com o desenho da situação provocada para facilitar a compreensão e visualização. 
dois lados binários, e aqueles/as que não conseguem se enquadrar são postos às margens, considerados/as abjetos/as, estranhos/as, travecos. Estes corpos à margem são os pré-operados, pós-operados, hormonizados, depilados, retocados, siliconados, maquiados. "Corpos inconclusos, desfeitos e refeitos, arquivos vivos de histórias de exclusão. Corpos que embaralham as fronteiras entre o natural e o artificial, entre o real e o fictício" (BENTO, 20o6: 19), que denunciam a não naturalidade das normas de gênero, sua falta de consenso na vida social. Como afirma a autora, a coerência dos gêneros está na ausência de ambiguidades. O dispositivo da transexualidade está em pleno funcionamento ao cortar, apontar, assinalar os excessos, produzindo realidades e ritualizando-as como verdades nas sentenças proferidas por olhares inquisitórios contra aqueles/as que cruzam a linha.

A mesma situação é inserida no grupo de personagens de Ártemis.

Julia - Ártemis: Eu acho que eu não interviria na situação, ela falou pra essa...? [...]

Ellena - Ártemis: mas ela está no seu direito ué, Ela se acha mulher, e ela é uma mulher... ela não tem o direito de definir quem é o outro, se ela se sente uma mulher ela vive como uma mulher e o outro, se se sente como uma mulher, e acabou... ela deixou o outro viver em paz, deixa os outros em paz.

Há um estranhamento menos explícito nas falas das personagens de Ártemis e, ao mesmo tempo, uma maneira de esquivar-se da situação, de modo a não se comprometer com a cena e com os preconceitos implícitos ou explícitos em relação a esses corpos 'antinaturais'.

Os estranhamentos e os estereótipos, o fato de serem inquiridos/as quanto à identidade de gênero, questionamentos acerca das imagens corporais, todos esses fatores nos levam a perceber que há uma expectativa, mesmo por parte dos/as transexuais, cobrando a interiorização e incorporação de determinadas estilísticas de gênero, a fim de serem socialmente aceitos/as no gênero identificado.

A cena continua:

Carolina - Ártemis: Eu acho que eu perguntaria quem ela, qual a importância que ela acha que tem pra julgar uma outra pessoa. E, se ela se diz assim tão cristã, porque que ela tá ofendendo uma pessoa e isso não tem nada a ver com a vida dela. Eu acho que o ponto que eu defenderia seria justamente esse, o que ela tá fazendo pra interferir na sua vida.

Luana - Ártemis: Mas... falou que ela é cristã?

Mestre: Não... Ela tem um crucifixo (na imagem).

Nesse momento, a personagem que proferiu a fala inquisitória contra a mulher trans diz que é de família e que a influência dessa pessoa não deveria prejudicar 
pessoas de bem, de família tradicional e cristã (cena criada pelo/a mestre em Ártemis). Ellena - Ártemis a questiona com relação a ser do bem, pois a forma como alguém assume seu gênero não muda seus valores e ética. A cena continua:

Mestre: E ela diria pra você: mas você sabia que isso é doença. Que tem $\mathrm{CID}^{13}$ pra isso. Você médica deveria saber. Como você trata seus pacientes?

Ellena - Ártemis: Eu falaria que ela está equivocada, que isso não é uma doença e ela tem que procurar se informar melhor.

Mestre: Aí ela olha pras médicas: Olha aí, médicas, vocês não podem me ajudar? Isso não é uma doença?

Luana - Ártemis: Não, que eu saiba não. Não estudei nada sobre isso. Estudei na melhor universidade da minha cidade e não tem nada falando disso. A gente tem que respeitar a pessoa pelo que ela é, do jeito que ela se veste e independente do que você for

$[\ldots]$

Julia - Ártemis: eu acho que a minha personagem não colocaria mais lenha na fogueira, porque pelo jeito essa aqui quer discutir, quer ganhar a causa, então eu chegaria nela e falaria só: você está bem vestida assim? Você escolheu vestir assim, então você pode se vestir do jeito que você quer. Então seria melhor ela ignorar a outra, porque o problema tá nessa que tá incomodada com a maneira que a outra tá vestida. Ela já escolheu se vestir da maneira que ela quer, colocar esse vestidinho aqui. Então ela não tem que se incomodar com a maneira que a outra escolheu para se vestir.

$[\ldots]$

Luana - Ártemis: [...] Eu não concordo com o jeito que ela é, mas isso não quer dizer que eu tenha que desrespeitar também e ser imoral com as coisas que eu falo [...].

As personagens tentam desconstruir a visão naturalizada referente à identidade de gênero e aspectos biológicos, mas demonstram não conhecer a respeito das normatizações, sobretudo aquelas que se legitimam pelo SUS (Sistema Único de Saúde), referente ao CID de Incongruência de Gênero que ainda prevalece legislando e patologizando corpos e condutas.

Na sequência, questionam-se acerca da busca de um modelo de feminilidade, afirmando que as escolhas são individuais, cada um/a opta pelas suas vestimentas, $o$ modo como assume determinada estilística, sem que isso interfira na vida do/a outro/a. Parece que a busca por implementar um modelo inatingível revela as possibilidades potenciais para transformações (BENTO, 2006), pois as próprias normas de gênero apresentam fragilidades, uma vez que estão assentadas em algo plástico, maleável e manipulável, que é o corpo. Para os/as transexuais, essas idealizações tornam-se mais 13 CID - Classificação Internacional de Doenças. 
comprometidas, pois suas subjetividades não advêm da estrutura biológica, abrindo espaço para descontinuidades e possíveis transformações. Para a autora, é importante compreender a visão que institui o/a transexual como enfermo e/ou transtornado, para se contrapor a ela, pensando as performances de gênero enquanto paródias, na perspectiva butleriana, desfazendo os limites e as fronteiras que separam o natural do artificial, o real do irreal, superando aspectos estereotipados das práticas transexuais, questionando a referência ao corpo sexuado.

Quando os/as transexuais atualizam em suas práticas interpretações do que seja um/a homem/mulher por meio de atos corporais materializados em cores, modelos, acessórios, gestos, o resultado é uma paródia de outra paródia, que desestabiliza a identidade naturalizada, centrada no homem e na mulher "biologicamente normais" (BENTO, 2006: 105).

Os padrões de masculinidades e feminilidades construídos socialmente refletem-se nas definições do que seja um/a transexual de verdade. Quando pensamos no aspecto corporal dos/as transexuais, as experiências que estruturam o gênero na sociedade põem em funcionamento o aspecto da normalidade que, novamente, volta-se à norma heterossexual. É como se, ao afirmar-se homem ou mulher, estivesse reiterando sou homem heterossexual/sou mulher heterossexual, evocando essas classificações como um dado natural, que determinasse a coerência e existência dos corpos sexuados (BENTO, 2006; BUTLER, 2003).

Quando as coerências de gênero e a norma heterossexual não coincidem, novamente entram em atrito as posições de sujeitos e as perguntas se expressam: "de que adianta ser trans?", como se fosse preciso garantir a legitimidade do gênero na heterossexualidade. "Porque ser uma mulher transexual e sentir atração por mulheres ou o seu contrário?”. São questões que se explicitam também nas reflexões das acadêmicas de Ártemis.

A genitalização da sexualidade é um dos desdobramentos do dispositivo da (trans)sexualidade que faz coincidir sensações com determinadas zonas corporais, reduzindo o corpo a zonas erógenas. Quando problematizamos essa questão, reconhecemos que há muitas possibilidades de viver o gênero, para além dos binarismos impostos. O/a transexual pode ser heterossexual, homossexual, bissexual, assexual e/ou outras variações da sexualidade e "isso não abala o sentimento de nãopertencimento ao gênero em que seu sexo o/a posiciona” (BENTO, 2006: 31).

Nos encontros para debater as intervenções e possibilitar a formação com as acadêmicas de Ártemis, essa discussão se fez presente.

Mestre: Eu posso ser trans homem e sentir desejo por homens. Fernando - Ártemis: E muita gente diria: De que adianta, então? Por que vai se vestir de homem se gosta de homem. [...] Foi aquela pergunta que você fez no primeiro dia, né. Da sua personagem. 
Cristiane - Ártemis: a minha personagem era uma mulher trans se ela... calma, por exemplo, se ela gostasse de homem, o que ela seria? Se ela gostasse de mulher o que ela seria? E ia depender do que ela nasceu ou ia depender do que ela se sente.

[...] Luiz Carlos - Ártemis: É o Bruce Janer que era um atleta muito famoso nos Estados Unidos e nesse último ano ele fez uma transformação e agora é Evelin, e ela continua gostando de mulheres. Só que agora no corpo de mulher. Então, só que ela ainda não saiu com ninguém, até porque, se sair vai dar um... né.

Larissa - Ártemis: Antes era hétero e, então, agora é lésbica.

Depreende-se que, implicitamente, o que segue orientando a classificação oficial de uma pessoa transexual deriva-se de uma mente heterossexual. Parece inconcebível um corpo-sexuado homem que se reconstrua como um corpo-sexuado mulher e que eleja como objeto de desejo uma mulher, pois uma mulher "de verdade" é heterossexual, há uma transgressão à norma (BENTO, 2006).

A normalidade está identificada com a heterossexualidade. Quando há esse segundo deslocamento corpo e gênero, tanto a sexualidade quanto a identidade de gênero divergem das normas de gênero. Recupera-se a preocupação de Butler (2003) conforme a qual a diferença sexual pode levar a uma coisificação do gênero e a um marco implicitamente heterossexual para a descrição do gênero, da identidade de gênero e da sexualidade.

É incompreensível que uma pessoa mude seu gênero e não assuma seu papel heterossexual na relação, visto que para muitos/as a motivação principal para a transexualidade é o desejo de manter relações sexuais heterossexuais, o que os/as leva a fazer a cirurgia. Desse ponto de vista, qual seria o sentido de fazer a cirurgia e definir-se como gay ou lésbica? Esse segundo deslocamento embaralha as categorias binárias que elaboram o olhar sobre os corpos (BENTO, 2006).

Nessa perspectiva, os corpos cobram de si o enquadramento. Enquanto não realizam o corte físico, na carne, e o corte simbólico, por meio de técnicas para dissimular os signos que os denunciam como membros do gênero rejeitado, parecem não efetivar as características que designam o gênero pretendido; realizam diversas intervenções corporais na busca de uma coerência entre as performances de gênero e o corpo apropriado para desenvolvê-las.

A necessidade de cirurgia aparece nesse contexto, na interpretação de muitos/ as, como se para viver a experiência do gênero oposto ao seu sexo biológico fosse preciso adequá-lo também, pois a experiência de ser mulher só é completa se há correspondência com a genitália e o ato sexual; o mesmo para os homens trans.

Assim, não existe um referente natural, original para se vivenciarem as performances de gênero, pois o original acabaria se referenciando no corpo (corpovagina-mulher, corpo-pênis-homem). Aqueles/as que constroem suas performances fora dessa norma são interpretados/as como cópias mentirosas do homem/da mulher de verdade. 
Nas performances, outra cena se relaciona à reiteração da cópia a uma referência original, corporificada na genitália. Os/as personagens estão em um banheiro público e se deparam com um homem trans sofrendo constrangimento ao tentar utilizar o banheiro masculino, por não ser considerado "homem de verdade".

Danilo - Ártemis: Mas, por exemplo, meu personagem é gay, ele vai usar o banheiro feminino ou não? se ele entrasse num banheiro feminino ele também ia passar por algum tipo de preconceito também, mas é a mesma situação. Ele é trans, só que o meu ele não se veste como mulher, se ele acha que ele deve se comportar usando o banheiro feminino, eu poderia entrar. E, a mesma coisa aqui... Eu acho que são... eu... eu como... é... homossexual, mas o meu gênero é masculino, eu to usando um banheiro de homem, mas eu também... mas eu acho que o desconforto maior seria ele machista comigo. Mas não, é com o outro, com o jeito da mulher que se veste como homem. Eu acho que eu tentaria argumentar ai e defender...

Cristiane - Ártemis: Eu argumentaria da forma que eu sou trans, só que eu perguntaria pro rapaz se, como ele se sentia, se ele se sente homem. Então, você tem que usar o banheiro masculino. E não é outra pessoa que tem que julgar isso ou não, é a própria pessoa. Como eu me julgo mulher, eu entro no banheiro feminino.

Dinho - Ártemis: ela se reconhece como homem, e é isso que ela tava fazendo ali, usando o banheiro de homem. Mas ela é mulher, se pegar o registro dela tá lá como fêmea.

Cristiane - Ártemis: No meu registro eu to lá como macho, e eu não vou poder usar o banheiro feminino? Não, não é assim... cada um se considera e cada um usa o banheiro que acha pertinente... pronto. E se ele olhasse pra mim e dissesse que eu estaria causando de novo. Nossa, mas o senhor está sendo machista e preconceituoso novamente.

Explicitam-se algumas questões: Danilo, aparentemente, fica confuso com relação à utilização do banheiro, pois ao mesmo tempo em que defende tal utilização levanta algumas questões, como "o jeito da mulher que se veste como homem", naturalizando a identidade ao sexo, reafirmando a perspectiva alimentada na cena de que não haveria ali um homem de verdade; outra questão pode ser evidenciada na fala de Dinho, pois o mesmo se refere ao homem trans no feminino, afirmando que ela é mulher pelo registro civil, ou seja, deslegitimando sua identidade no que concerne ao direito; Cristiane complementa alegando que seu registro também é oposto ao gênero que assumiu. Esses/as personagens defendem a utilização do banheiro, mas acabam se confundindo em suas defesas, pautando-se na perspectiva do sentir-se homem ou mulher, mas não necessariamente sê-lo de verdade. 
$\mathrm{Na}$ continuidade da cena, entra em foco a questão da cirurgia como comprovação de uma identidade de gênero genuína. Cristiane, ao ser questionada sobre o fato de ser mulher, responde:

Cristiane - Ártemis: É, quem garante... que eu sou homem? Eu já passei por cirurgia, então, agora eu sou uma mulher, e não tem discussão. Da mesma forma que não tem discussão um homem trans usar o banheiro masculino.

Mestre: Ai ele fala pra você que você passou por cirurgia mas você não vai poder ter um filho, você não é uma mulher...

Cristiane - Ártemis: Quem disse que eu não posso adotar? Eu posso adotar. Eu não ficaria grávida, mas eu posso adotar. O que importa não é... o que importa é o amor que eu teria por esse filho e não a gestação.

Dinho - Ártemis: Do mesmo modo que nem todas as mulheres que nascem mulheres podem ter filhos. Não são todas.

Mestre: Aí, ele fala: mas o que esse filho ia ter em casa, homem pode entrar no banheiro de mulher, mulher pode entrar no banheiro de homem.

Danilo - Ártemis: Ele ia aprender que existe afeto...

Percebe-se na fala de Cristiane que a garantia de que se é uma mulher está na cirurgia, na reconstrução da genitália, fato inquestionável do corpo feminino, corpo remodelado segundo as expectativas de gênero. Questionamos o grupo com relação à maternidade, já que o 'destino biológico' de muitas mulheres seria este, como forma de comprovar a identidade de gênero. Nesse ponto, os/as três personagens defendem que ser mulher não é necessariamente gerar filhos/as biologicamente, mas amar e ter afeto.

A mesma cena do banheiro é inserida no grupo de Pandora. Ao se situarem diante da situação de preconceito, as personagens reagem:

Giovana - Pandora: Ahhh, Sai daqui o [direcionado à pessoa que executou o preconceito].

Mariane - Pandora: elas estariam lá fazendo xixi bem de boa (risos).

Mestre: Vocês não reagiriam diante da situação?

Giovana - Pandora: Como usuária até ela até pode usar.

Mariane - Pandora: Eu acho que ele pode usar, sem problema. Agora, eu não ia me meter na briga dos outros. Quando os outros tão brigando eu largo brigar (risos).

Giovana - Pandora: até porque a gente nem sabe se ela tem pênis ou não. Vai que ela já fez a cirurgia.

Mariane - Pandora: O banheiro tá com a porta fechada, qual o problema? 
Nessa cena também fica evidente a necessidade de cirurgia para, de fato, garantir a materialidade da identidade de gênero. E, a todo o momento, mesmo tendo dito que se tratava de homem trans tentando utilizar o banheiro público, as personagens se referiam no feminino à personagem da situação, questionando a presença da genitália que garantiria sua genuína transição.

Em relação a esse aspecto, Andrade (2012) afirma que, mesmo que alterem o corpo cirurgicamente e tenham todos os 'trejeitos' próprios do gênero com o qual se identificam, o/a transexual e o/a travesti não vão conseguir aval definitivo da sociedade, porque sempre haverá a necessidade de provar a originalidade, a essência a partir da natureza e da biologia. O olhar milimetricamente destinado aos/às travestis e transexuais sempre está à procura da anatomia sexual do nascimento, da essência biológica.

Este episódio mostra como a anatomia se torna relevante nos discursos:

Cristiane - Ártemis: Mas eu sou uma menina. Tenho órgãos femininos, o que me tira de ser menina?

Mestre: Daí ela olha pra você e ela fala assim: Mas você não nasceu menino?

Cristiane - Ártemis: Nasci, mas agora não sou mais. Existem mudanças na vida, tanto de ideias quanto de gênero.

Mestre: E ela fala assim: Ah não, mas isso não tá certo. Isso não é natural.

Cristiane - Ártemis: Por que não é natural? Você não nasceu

Nesse sentido, desconstruir os modos como olhamos as performances de gênero "significa admitir e analisar operações de exclusão, de rasura, de violenta forclusão ${ }^{14}$, de abjeção e seu inquietante retorno, presentes na construção discursiva do sujeito" (SALIH, 2015: 115).

Para Bento (2006), vários são os pontos de unidade entre o discurso feminista e transexual, como o fato de ainda lutar pelo direito ao próprio corpo, negando a submissão ao destino biológico orientado pela genitália. Não são todos/as os/as transexuais que querem realizar intervenções cirúrgicas. Muitos/as não querem a cirurgia, querem e reivindicam, exclusivamente, reconhecimento social, mudanças nos documentos. "Nesses casos, a aparência do gênero identificado é obtida com o uso de hormônio, silicone e maquiagem” (BENTO, 2006: 106). Contudo, socialmente, continuarão a ser identificados como 'veado/traveco/sapatão', o que salienta a

14 No livro Bodies that Matter, Butler (1993) irá utilizar um termo psicanalítico para significar como as identidades sexuadas são assumidas através de violenta rejeição e exclusão (ou "forclusão") das identidades que supostamente não pesam, isto é, que não contam no contexto da matriz heterossexual que tem interesse particular em manter sua própria estabilidade e coerência às custas de "outras" identidades. 
necessidade de repensarmos as classificações alicerçadas nos corpos sexualmente apropriados, visto que o sentimento de pertencer ao gênero contrário ao que seu corpo lhes informa não necessariamente leva ao desejo pela cirurgia. Para muitos/as transexuais, não é a cirurgia que irá garantir a coerência identitária que procuram; para outros/as, porém, a cirurgia pode representar a possibilidade de ascenderem à condição humana. A cirurgia, para quem decide realizá-la, possibilita acumular mais “capital de gênero" (BENTO, 2006: 218), que irá culminar no reconhecimento que se pretende definitivo com a mudança dos documentos.

Com relação ao uso do banheiro, posteriormente às intervenções do RPG, questionamos as acadêmicas das pesquisas sobre qual seria a postura delas, como educadoras, em situações similares, na vida real. Uma situação real foi então explicitada. Um menino começou a se vestir de menina, assumindo, portanto, uma identidade feminina, e foi usar o banheiro feminino. As crianças da escola começaram a querer impedi-la de acessar o espaço, e a diretora da escola, assumindo uma postura autoritária, retirou a criança do banheiro, colocando-a em situação de humilhação, fato que gerou vaias e deboche em relação a essa criança, por parte das demais.

Luana - Ártemis: Então, esse inclusive foi um questionamento, [...] que são situações que eu como professora, [...] eu não saberia o que fazer. Eu não saberia realmente. Falta realmente isso na nossa graduação de não saber lidar com essas novas questões que estão na nossa sociedade, estão presentes na sala de aula né. Bom, se não estão tão agora, vão daqui um tempo, estar muito mais presente.

$[\ldots]$

Cristiane - Ártemis: Eu acho que dependendo da minha posição, eu tentaria fazer o que estivesse ao meu alcance [...] trazer um pouco mais de conhecimento pra escola, porque é, já não basta a criança ter que lidar com "eu não me sinto bem assim e eu ainda vou ter que frequentar um banheiro oposto do que eu me sinto". Eu acho que é muito confuso pra cabeça da criança, que já está confusa, então eu tentaria melhorar pra que ela não tivesse problemas psicológicos posteriormente.

Luiz Carlos - Ártemis: Eu acho que como professora, eu iria tentar intervir no momento que a criança está sendo humilhada e, com certeza eu tentaria um contato com os pais.

$[\ldots]$

Dinho - Ártemis: [...] eu acho difícil um professor intervir numa situação como essa. Se ele vai intervir é, a favor da criança poder usar o banheiro, e aí acaba comprando briga com "N" famílias então, é difícil o professor intervir 
Cristiane - Ártemis: Acho que muita gente pensa assim, "Ele é um, se eu lutar pelos direitos dele eu posso causar uma intriga com a escola inteira, então melhor eu, sei lá...

Dinho - Ártemis: Se um professor defendesse seria minoria, porque gente, é um fato, o professor colocar a cara a tapa e falar "não, a criança tem o direito de frequentar o banheiro"! Comprar uma briga com a direção ou com as outras famílias, com o município e sei lá tem outras pessoas que elas estão acima e elas que dão a ordem né.

$[\ldots]$

Cristiane - Ártemis: Na escola, geralmente quando alguém se opõe, se opõe a alguma coisa, você sofre retaliação.

Nessas falas, fica explícita a falta de formação para lidar com tais questões e, além disso, há o medo que muitos/as educadores/as têm ao tocar nesse assunto que, considerado tabu, conforme o pensamento da maioria das pessoas, não deve ser falado na escola, pois poderá incitar a comportamentos 'inapropriados', não condizentes com a norma (sexo biológico). Há um grande receio por parte de alguns/mas educadores/as de que haja retaliação da escola, dos/das pais/mães e da comunidade em geral, o que realmente tem acontecido no cenário nacional. O Brasil atravessa um período de demonização dos Estudos de Gênero, das proposições feministas e da militância LGBTTTQIA sobre os direitos das pessoas cujos Gêneros e as sexualidades não coincidem com os marcadores sociais cisGêneros e heteronormativos e lutam por reconhecimento, por direitos sexuais, reprodutivos e por políticas públicas de amparo a não violência sexual e à disseminação de preconceitos e sexismos. O Escola Sem Partido ${ }^{15}$, como instrumento de coerção e perseguição do trabalho docente, estabelece obrigações morais, condenações, patrulhamento de conteúdos históricos, socioculturais e econômicos em função de uma educação totalmente técnica, descontextualizada, acrítica e pseudocientífica. Também propõe, como um instrumento de censura, a gravação das aulas pela/o estudante, visando instaurar um ambiente de coerção, perseguição e vigilância ao trabalho docente. Nesse contexto, para além dos diferentes instrumentos legais que legitimam o trabalho com essas

15 O ESP insurgiu no país, ainda que inexpressivamente, em 2004, como iniciativa conjunta de estudantes e familiares empenhados em promover mudanças na estrutura jurídica do direito à educação e de regularizar a liberdade de cátedra ao ditar regras para a livre expressão nas escolas brasileiras. De acordo com o site oficial do ESP, é necessário "descontaminar" a escola de posições político-ideológicas cujos pretextos seriam transmitir uma visão crítica da realidade através da doutrinação dos estudantes. Sendo assim, o ESP tem avançado consideravelmente no Brasil. Alegando a necessidade de neutralidade na educação, o movimento corrobora para retirar os estudantes dos processos democráticos de produção de saberes e da vida pública escolar. Perscruta temas de relevância social como a inserção das diferenças étnicas, de gênero, de classe transversalizadas nos conteúdos das disciplinas e vividas junto aos debates do ensinar e aprender (CARVALHO; POLIZEL; MAIO, 2016). 
questões e tornam inconstitucionais ações como do ESP, há o medo propagado pelos discursos perseguidores ao trabalho docente.

Em muitos aspectos, nossa sociedade se desresponsabiliza em relação ao respeito à diversidade e ao debate do tema, e muitos discursos de ódio têm sido propagados. Andrade (2012: 112) afirma que o fato de saírem da rota, de cruzarem a fronteira estabelecida, faz muitos/as travestis e transexuais pagarem um preço alto, como serem perseguidos/as por parte da sociedade, estigmatizados/as como incapazes de alcançar uma identidade de gênero original ou uma aparência física coerente com o gênero. Muitos/as são violentamente cooptados/as para outros caminhos que foram e que são oficializados como espaço de travesti, "como as pistas de dança, as pistas do teatro, as pistas do desfile, as pistas da rua, as pistas da prostituição”.

Em uma cena do jogo, um transexual que trabalhava de garçom em um restaurante foi demitido injustamente, por preconceito. Os dois grupos passam pela situação. Em Ártemis, as personagens interviriam na situação, como Luana.

Luana - Ártemis: Faria ele pensar que, independente se é um transexual, se é um outro gênero que... independente de qualquer coisa é uma pessoa, é um funcionário dele, ela não pode tratar desse jeito, vai ver no estatuto dos direitos trabalhistas, vê se pode fazer isso. Isso é uma pessoa, independente, é um ser humano, deve ser tratado da mesma forma, como qualquer outro ser humano.

Em Pandora, algumas personagens ficam divididas.

Marieta - Pandora: Eu acho que a Mari ia ficar um pouco neutra. Mestre: Ela ia ficar um pouco neutra? Porquê?

Marieta - Pandora: Mesmo indignada, ela ia ficar um pouco neutra. Mesmo indignada eu acho que ela não se intrometeria. Indignada acho que ela ia ficar, mas ir na frente e tomar uma atitude eu acho que ela não faria.

Giovana - Pandora: A Giovana ia agir, ela ficaria possuída pelo espírito ratatauí... (risos gerais). [...]

Mariane - Pandora: Eu acho que não tem que demitir o rapaz porque ele é transexual. Ele tá fazendo o trabalho dele da maneira correta é. Tem que demitir quando não faz o serviço de maneira correta, não é? Seja lá quem for... (risos).

Marieta - Pandora: Eu acho assim, A Marieta, independente a orientação sexual dele, ela tomaria uma atitude por ser uma pessoa que não gosta de confusão. Mesmo que fosse um homossexual, um hétero ou qualquer um, como a cena tem muitas pessoas assistindo, e provocaria um alvoroço, então ela ficaria neutra diante da situação, não pela orientação do garçom. Qualquer um ali tinha que manter o emprego. Foi um erro que cometeu 
no trabalho, né. Tinha que dar uma chance. Mas eu acho que ela ficaria neutra sim por não gostar de confusão, causaria tumulto.

Mariane - Pandora: Começar uma discussão com o dono lá, nem a Mariane, nem eu começaria, eu só observaria e desaprovaria.

Marieta - Pandora: Mesma coisa eu.

Giovana - Pandora: Já a Geovana não, o que ela acha errado ela fala, na cara (risos) ela não é de mandar recado.

Nesse caso, apreendemos que em Pandora duas personagens não interfeririam na situação, mesmo achando que a atitude do patrão estava errada. Como salientamos, é um tabu que acaba gerando desconhecimento e apatia, como nos diversos casos cotidianos de violência contra travestis e transexuais no país, muitos deles à luz do dia, com diversos/as telespectadores/as apáticos/as, sem reação diante da violência e do descaso com a população trans. Para Berenice Bento (2006), não se trata de construir um/a transexual vítima, mas de se perguntar o que significa ser uma pessoa normal, quais os mecanismos e os critérios para definir, classificar, catalogar alguém como normal ou anormal.

No encontro de debates com as acadêmicas de Ártemis, quando perguntamos qual o lugar que tem sido reservado às travestis e transexuais, muitas responderam que elas estão nas esquinas, nas ruas.

Fernando - Ártemis: Porque elas ficam lá. Porque elas não são aceitas nos outros lugares.

Dinho - Ártemis: Se elas forem procurar um emprego elas não conseguem. Porque quem vai dar um emprego pra uma travesti? É muito difícil.

Fernando - Ártemis: Por medo também.

Dinho - Ártemis: Eu vi uma reportagem em que a equipe ficou junto com ela, e ela foi entregando muitos currículos e ia em alguns lugares. E quando ela chegava pra fazer entrevista, ela não foi chamada em nenhum. Ela foi, eu acho que, em uns trinta assim, na sequência e ninguém... e ela tinha outros atributos necessários pra vaga, só que ela não era chamada. [...] E ela conseguiu um emprego num negócio de vender acessórios pra carnaval, foi o único lugar que aceitaram ela.

Cristiane - Ártemis: [...] Eu tenho amigos gays e aí um dia eles levaram uma travesti e meu pai e minha mãe estavam na casa do meu irmão. Aí eles começaram a conversar, perguntar algumas coisas, né, e aí a moça falou que ela só conseguia emprego em salão de beleza, que era onde aceitavam ela.

Notamos como os espaços ocupados por muitos/as travestis têm sido as ruas, os espaços deslegitimados socialmente, renegados pela sociedade como locais de ocupações indignas; ou espaços definidos, como salão de beleza, espaços de festas e de outros entretenimentos. Logo, não é uma questão de vitimização, mas de 
reconhecimento das identidades. A afirmação da identidade, como apontam Pocahy e Dornelles (2010), diz respeito aos jogos de resistências, como uma estratégia que logo deverá desaparecer caso não se queira sucumbir aos novos arranjos normativos, ou seja, aos perigos de essencializar a diferença.

Conforme Larissa Pelúcio (2009), para responder à pergunta sobre quem são as travestis é preciso reconhecer os locais, as trilhas e os corpos que não se cansam de ser nômades. Corpos plurais que não possibilitam ser enquadrados em formas fixas.

Pensando na construção desses corpos, voltamo-nos a um período crucial na construção identitária, o da escolarização. Para muitos/as transexuais, a escola é lembrada como um espaço de terror onde vivenciaram todo tipo de preconceito, sendo saturada, produtora e reprodutora de homofobia (BENTO, 20o6; LOURO, 2007a e b; POCAHY; DORNELLES, 2010; CAETANO; GARCIA, 2010).

Com foco nesse aspecto, a última cena acontece na sala de aula, com os/as personagens de ambas as cidades: Ártemis e Pandora. Ao passarem pelo corredor da escola, alguns/mas personagens observam a chamada sendo realizada em uma sala e o enunciar insistente da professora: "Simone, Simoneee" (MESTRE). Após repetidas vezes, uma criança se levanta e pede para que a professora corrija na chamada: "É Simon, professora" (MESTRE).

Em um primeiro momento, as personagens de Ártemis perguntam se seria a primeira vez ou se o fato é recorrente. Explicitamos que a professora já havia sido orientada a fazer a alteração na chamada e se recusava.

Larissa - Ártemis: Não, daí eu chamaria a atenção da professora. "Chama do jeito que ele pediu". Eu falaria isso. No momento.

Mestre: aí a professora fala pra você: Não, mas se for assim eu posso colocar um apelido nos meninos que querem colocar o apelido na lista de chamada.

Larissa - Ártemis: mas é diferente, porque o nome social, digamos assim o registro, alguma coisa assim, são nomes que a gente atribui aos indivíduos, digamos assim, são nomes que são clássicos, que todo mundo já conhece. Apelidos vai depender muito da característica, mas ele não só acha adequado chamar pelo nome, ele se veste também, de forma que tem a característica de que "Eu gosto de ser assim, eu me acho homem", não sei, digamos assim, se sente assim, então pra avaliar que isso não é uma brincadeira, não é assim de dar apelidos por pura graça, cicatrizar de uma forma "aí, eu sou fulano de tal, porque ela é uma artista e quer ser chamada assim, não é tão a sério quanto uma identidade. Isso já passa a ser uma identidade tanto da pessoa e tanto pra sociedade, porque nome social é... já tem vários processos que está acontecendo mesmo, isso daí já chega a vigorar como lei, e tal, não é mais uma brincadeira que todo mundo tem essa opção, essa liberdade, digamos assim, de se atribuir apelidos, isso daí já é um nome, e não... eu defenderia nesse ponto. 
Ao longo das problematizações posteriores em Ártemis, Larissa se posiciona defendendo a utilização do nome social, hesitando em alguns momentos, por medo de retaliações da escola e da comunidade. Mas ao perceber que a escola toda já havia feito a alteração, que apenas aquela professora hesitava, defendeu a posição argumentando sem medo.

Em Pandora, a situação foi um pouco diferente. As personagens começam o diálogo:

Lia - Pandora: Judiação (risos).

Ruth - Pandora: Eu não ia me intrometer não. Eu não tava fazendo a chamada, né?

Mestre: Não, você não estava, você estava passando no corredor, como pedagoga.

Ruth - Pandora: Pedagoga? Eu não ia me intrometer perto dos alunos. Depois eu ia chamar ela na minha sala e falar pra ela procurar se informar melhor dos alunos que ela tem na sala por conta dessa diferença que tá tendo hoje. Como tem lésbica, tem gay, tipo assim, só pra não ter aquela coisa de preconceito, que o professor tem que dar o exemplo, e fazendo algo assim imagina a polêmica que vai virar.

Mestre: Aí você vai pra sua sala e um aluno vai chorando na sua sala porque ele estava se sentindo humilhado, os colegas começaram a fazer bullying com ele e ele não estava mais conseguindo ficar na sala. O que você faria?

Ruth - Pandora: Eu não ia falar pra ele que era certo o que ele tava fazendo. Eu ia falar pra ele partir do caminho que ele acha correto, que se ele tava feliz naquele caminho pra ele não se importar com que as pessoas pensam, e sim o que sente e como ele tá feliz.

Mestre: Mas, o professora, o que que você vai fazer então. Eu não consigo nem ficar naquela sala mais. As pessoas tão me humilhando, tão tirando sarro de mim.

Ruth - Pandora: O que eu posso é conversar com os alunos, falar pros alunos respeitar cada um. Da mesma forma que ele tem a diferença dele, tem aluno que é deficiente, ou seja, tem que respeitar a deficiência dele. Tem aqueles que parecem perfeitos, só que quando abre a boca não fala nada com nada. Cada um tem um tipo de deficiência.

Observamos que Ruth trata a transexualidade como uma patologia e só decide intervir quando é colocada em uma função em que é necessária a intervenção.

Refletindo sobre o contexto, precisamos compreender que a infância é um momento em que a identidade vai se construindo alicerçada em processos citacionais binários relacionados aos gêneros (BENTO, 2006). A escola, enquanto uma instituição social, marcada pelos preconceitos e estereótipos, acaba reproduzindo e reiterando essas noções binárias. Como educadoras em formação, é importante que entendam a instabilidade e o constante formar das identidades, para que possam abrir espaços 
à produção de fissuras que transformem os discursos e possibilitem à escola ser um espaço acolhedor e consciente da sua função social.

\section{Considerações (sempre) provisórias}

Ao questionarmos o lugar do corpo na sociedade contemporânea, buscamos reconhecer a existência de outras possibilidades de constituição das identidades e subjetividades, mediante práticas sociais que (re)pensem os espaços e/ou se construam em outros espaços, corpos que se produzam em heterotopias, e que possam ter a liberdade de se constituírem como corpos heterotópicos, e que o lado de fora (corpos que hoje pertencem à margem, a excentricidade) seja apenas mais um, de tantos tempos-espaços que poderíamos ocupar.

Pensar as subjetividades trans é discutir os territórios plurais alicerçados na biopolítica contemporânea, que se desenham nas construções acadêmicas, nas mídias, nas redes sociais e nos diferentes cenários que revelam novas/outras formas de ser e estar no mundo e de contar-se. É na tensão entre assujeitamentos e resistências que há a possibilidade de desestabilização dos e nos dispositivos de controle. Assim, pensar as vivências trans é refletir sobre os processos de negociação, de subversão às normas que uniformizam e reduzem as experiências a um caráter patológico, medicalizante e binário, vislumbrando um outro cenário possível.

Quando refletimos sobre as questões identitárias na formação docente, estamos reconhecendo a necessidade de desconstrução das normas e binarismos que impõe modos de ser e estar no mundo, produzindo processos de subjetivação alicerçados em pedagogias culturais que legitimam exclusões e violências. $\mathrm{O}$ desconforto e o estranhamento foram perceptíveis em diversas cenas que colocavam em evidência características socialmente "não aceitas" dentro dos padrões de normalidade, como nos momentos em que personagens transexuais e travestis encenavam e evidenciavamse enquanto tema de debate. Várias foram as inserções desses/as personagens em situações de violência e houve momentos em que essas violências provocaram revolta e indignação num movimento de defesa e, também, momentos em que o deboche se fez presente. Entretanto, em todos os casos em que essa foi a temática em ação, os/as personagens foram enfáticos/as quanto a não saberem como agir diante da situação, sobretudo quando acontecia no ambiente escolar, fato que remete à incapacidade de agir frente às demandas identitárias que estão cotidianamente sendo enviadas para as zonas de apagamento.

A proposta possibilitou constatar a necessidade de formação dos/as docentes para a sensibilidade aos temas, no sentido de prepará-los/as para atuarem com consciência nos diferentes espaços educativos, sendo sensíveis aos danos sociais, culturais e psíquicos causados pela manutenção de situações de intolerância, discriminações, sexismos, homofobias e tantos outros modos de exclusão criadores de zonas de apagamento. 
Buscamos a possibilidade de contribuir para estruturar uma formação inicial que contemple a diversidade e reconheça as diferenças como constituintes do nosso tempo, atributos necessários para a constituição das nossas subjetividades. Esperamos que, com potencialidade educativa, a formação inclua efetivamente as experiências, os pensamentos e as trajetórias, possibilitando o reconhecimento e a valorização do/a outro/a no processo de constituição da identidade docente.

\section{Referências}

ANDRADE, Francisco Leal de. (2011). Determinismo biológico e questões de gênero no contexto do ensino de biologia: representações e práticas docentes do Ensino Médio. Dissertação (Mestrado em Ensino, Filosofia e História das Ciências) - Programa de Pós-Graduação em Ensino, Filosofia e História das Ciências, Universidade Federal da Bahia, Salvador.

ANDRADE, Flávio. (2015). Caminhos para o uso do RPG na Educação. Disponível em: <http://www.uff.br/aleph/textos_em_pdf/caminhos_para_o_uso_do_rpg_na_ educacao.pdf>. Data de Acesso: 05 fev. 2015.

ANDRADE, Paula Deporte de. (2016) "A invenção das pedagogias culturais". In: CAMOZZATO, Viviane Castro; CARVALHO, Rodrigo Saballa de; ANDRADE, Paula Deporte de. Pedagogias Culturais: a arte de produzir modos de ser e viver na contemporaneidade. 1. ed. Curitiba: Appris. p.22-38.

ÁVILA; Simone; GROSSI, Miriam Pillar. (2010). "Transexualidade e movimento transgênero na perspectiva da diáspora Queer". In: V CONGRESSO DA ASSOCIAÇÃO BRASILEIRA DE ESTUDOS DA HOMOCULTURA - ABEH, Natal. Anais eletrônicos... Natal: UFSC, p.1-17. Disponível em: <http://nigs.paginas.ufsc. $\mathrm{br} /$ files/2012/o1/TRANSEXUALIDADE-E-MOVIMENTO-TRANSG\%C3\%8ANERONA-PERSPECTIVA-DA-DI\%C3\%81SPORA-QUEER-Simone-\%C3\%81vila-e-MiriamPillar-Grossi.pdf>. Data de Acesso: 04 fev. 2016.

BENTO, Berenice. (2006) A reinvenção do corpo: sexualidade e gênero na experiência transexual. Rio de Janeiro: Garamond.

BUTLER, Judith. (1993). Bodies that Matter: on the discursive limits of 'sex'. Nova York: Routledge.

BUTLER, Judith. (20030. Problemas de gênero: feminismo e subversão de identidades. Rio de Janeiro: Civilização Brasileira. 
CABALEIRO, Suely da Silva Xavier. O RPG Digital na Mediação da Aprendizagem da Escrita. 2007. 194 f. Dissertação (Mestrado em Educação e Contemporaneidade) Universidade do Estado da Bahia, Salvador, 2007.

CAETANO, Marcio Rodrigo Vale; GARCIA, Regina Leite. (2010). "Corpo polissêmico: a trajetória e os atos de currículos de uma professora que transita na inteligibilidade social de gênero". Instrumento. R. Est. Pesq. Educ. Juiz de Fora/MG, v. 12, n. 2, p.113-123, jul./dez.

CARVALHO, Fabiana Aparecida de; POLIZEL, Alexandre Luiz; MAIO, Eliane Rose. (2016). "Uma escola sem partido: discursividade, currículos e movimentos sociais". Rev. Semina: Ciências sociais e humanas, Londrina, v. 37, n. 2, p. 193- 210.

COSTA, Marisa Vorraber. (2007). "Pesquisa-ação, pesquisa participativa e política cultural de identidade”. In: COSTA, Marisa Vorraber (Org.) Caminhos investigativos II: Outros modos de pensar e fazer pesquisa em educação. 2. ed. Rio de Janeiro: Lamparina, p. 91-116.

FISCHER, Rosa Maria Bueno. (2007). "Verdades em suspenso: Foucault e os perigos a enfrentar”. In: COSTA, Marisa Vorraber (Org.) Caminhos investigativos II: Outros modos de pensar e fazer pesquisa em educação. 2. ed. Rio de Janeiro: Lamparina, p.4970.

FOUCAULT, Michel. (1988). História da sexualidade I: A vontade de saber. 13 ed. Rio de Janeiro: Graal.

FOUCAULT, Michel. (1996). A ordem do discurso: Aula inaugural no College de France, pronunciada em 2 de dezembro de 1970. São Paulo: Loyola.

FOUCAULT, Michel. (1997). Microfísica do Poder. 11 ed., Rio de Janeiro: Graal.

FOUCAULT, Michel. (200o). Vigiar e punir: o nascimento da prisão. 22. ed. Petrópolis/ RJ: Vozes.

FOUCAULT, Michel. (2013). O corpo utópico, as heterotopias. São Paulo: N-1 edições.

FRANÇA, Fabiane Freire. (2014). Representações sociais de gênero e sexualidade na escola: diálogo com educadoras. Tese (Doutorado em Educação) - Programa de PósGraduação em Educação, Universidade Estadual de Maringá, Maringá.

HALL, Suart. (2016). Cultura e representação. Rio de Janeiro: Ed. PUC-Rio: Apicuri. 
KRISTEVA, Julia. (1982). Poderes del Horror: Sobre la abyección. Tradução de Leon S. Roudinez. New York: Columbia University Press. Disponível em: <http://www. carlosbermejo.net/Seminario\%2ovirtual2\%20-1/poderes\%2odel\%2ohorror.pdf>. Data de Acesso: 20 jul. 2017.

LIMA, Fátima. (2014). Corpos, gêneros, sexualidade: políticas de subjetivação. Porto Alegre: Rede UNIDA.

LOURO, Guacira Lopes. (2001). “Teoria queer: uma política pós-identitária para a educação". Revista Estudos Feministas, Florianópolis, v.9, n.2, p.541-553.

LOURO, Guacira Lopes. (2007a). Gênero, sexualidade e educação: uma perspectiva pós-estruturalista. Petrópolis/RJ: Vozes.

LOURO, Guacira Lopes. (2007b). "Currículo, gênero e sexualidade: o "normal”, o "diferente” e o "excêntrico"”. In: LOURO, Guacira Lopes; FELIPE, Jane; GOELLNER, Silvana Vilodre (Orgs.). Corpo, gênero e sexualidade: um debate contemporâneo na educação. 3. ed. Petrópolis: Vozes, p.41-52.

MAGAlHÃES, Fernanda. (2010). Corpo Re-construção Ação Ritual Performance. Curitiba: Travessa dos Editores, 2010.

NAVARRO-SWAIN, Tânia. (2002). "As teorias da carne: corpos sexuados e identidades nômades". Labrys, Estudos Feministas, ns.1-2, jul./dez. <Disponível em: <https:// www.labrys.net.br/labrysı_2/anahita1.html>. Data de Acesso: o5 ago. 2013.

Organização Mundial da Sáude (OMS). (2018). ICD-11: Classifying disease to map the way we live and die coding disease and death. Disponível em: <https://www.afro.who. int/news/icd-11-classifying-disease-map-way-we-live-and-die>. Data de acesso: 10 fev. 2019.

PELÚCIO, Larissa. (2009). Abjeção e desejo: uma etnografia travesti sobre o modelo preventivo de Aids. São Paulo: Annablume.

POCAHY, Fernando; DORNELLES, Priscila Gomes. (2010). "Um corpo entre o gênero e a sexualidade: notas sobre educação e abjeção”. Instrumento, Juiz de Fora/MG, v. 1, n. 1, p. 125-135, jan./jun.

PRECIADO, Paul B. (2011). "Multidões Queer: notas para uma política dos anormais". Revista Estudos Feministas, Florianópolis, v.19, n.1, p.11-20, jan./abr.

SALIH, Sara. (2015). Judith Butler e a Teoria Queer. Belo Horizonte: Autêntica. 
SOUZA, Nadia Geisa Silveira de. (2016). "Discutindo práticas implicadas na produção do corpo. In: CAMOZZATO, Viviane Castro; CARVALHO, Rodrigo Saballa de; ANDRADE, Paula Deporte de. Pedagogias Culturais: a arte de produzir modos de ser e viver na contemporaneidade. 1. ed. Curitiba: Appris. p.39-6o.

Recebido em 01/04/2020.

Aceito em 28/10/2020. 